\title{
Hydrogen sulfide is a regulator of mammary gland development in prepubescent female mice
}

\author{
JING ZHANG ${ }^{13^{*}}$, JIAYI YE ${ }^{2,3^{*}}$, CONG YUAN $^{2,3}$, QIN FU ${ }^{2,3}$, FENGLIN ZHANG ${ }^{2,3}$, XIAOTONG ZHU ${ }^{2,3}$, \\ LINA WANG $^{2,3}$, PING GAO ${ }^{2,3}$, GANG SHU $^{2,3}$, SONGBO WANG ${ }^{2,3}$, QIANG LIU ${ }^{1}$ and QINGYAN JIANG ${ }^{2,3}$ \\ ${ }^{1}$ College of Animal Science, Shanxi Agricultural University, Jinzhong, Shanxi 030801; \\ ${ }^{2}$ Guangdong Provincial Key Laboratory of Animal Nutrition Control, College of Animal Science; \\ ${ }^{3}$ National Engineering Research Center for Breeding Swine Industry, South China \\ Agricultural University, Guangzhou, Guangdong 510642, P.R. China
}

Received January 27, 2020; Accepted July 9, 2020

DOI: $10.3892 / \mathrm{mmr} .2020 .11462$

\begin{abstract}
The present study aimed to investigate the effects of exogenous $\mathrm{H}_{2} \mathrm{~S}$ on mammary gland development in pubescent mice and to explore the underlying mechanism. The mouse mammary epithelial cell line $\mathrm{HC} 11$, along with $\mathrm{C} 57 \mathrm{BL} / 6 \mathrm{~J}$ mice, were treated with different concentrations of sodium hydrosulfide (NaHS), which is a donor of $\mathrm{H}_{2} \mathrm{~S}$. The $\mathrm{HC} 11$ cell viability, pubescent mammary gland development, and the involvement of proliferative proteins and pathways were assessed by CCK-8 assay, EdU assay, whole mount staining, H\&E staining, western blotting and reverse transcription-quantitative PCR. Both in vitro and in vivo, a low concentration of NaHS $(100 \mu \mathrm{M}$ in vitro; $9 \mathrm{mg} / \mathrm{kg}$ in vivo) significantly promoted the viability of HC11 cells and the development of mammary glands by increasing the expression of the proliferative markers cyclin D1/3 and proliferating cell nuclear antigen. However, a high concentration of NaHS $(1,000 \mu \mathrm{M}$ in vitro; $18 \mathrm{mg} / \mathrm{kg}$ in vivo) inhibited $\mathrm{HC} 11$ cell viability, mammary gland development and the expression levels of proteins involved in
\end{abstract}

Correspondence to: Professor Qiang Liu, College of Animal Science, Shanxi Agricultural University, 1 Mingxian Road, Taigu, Jinzhong, Shanxi 030801, P.R. China

E-mail: liuqiangabc@163.com

Professor Qingyan Jiang, Guangdong Provincial Key Laboratory of Animal Nutrition Control, College of Animal Science, South China Agricultural University, 483 Wushan Road, Tianhe, Guangzhou, Guangdong 510642, P.R. China

E-mail: qyjiang@scau.edu.cn

*Contributed equally

Abbreviations: Akt, protein kinase B; CCK-8, Cell Counting Kit- 8 ; FBS, fetal bovine serum; GCs, granulosa cells; mTOR, mammalian target of rapamycin; PCNA, proliferating cell nuclear antigen; PI3K, phosphatidylinositol 3-kinase; pen/strep, penicillin/streptomycin

Key words: hydrogen sulfide, mammary gland ductal development, pubescent mice proliferation. Subsequent experiments revealed that NaHS regulated the phosphatidylinositol 3-kinase (PI3K)/protein kinase B (Akt)-mammalian target of rapamycin (mTOR) signaling pathway during this process. In vivo, intraperitoneal injection of low concentration NaHS $(9 \mathrm{mg} / \mathrm{kg}$ ) activated the PI3K/Akt-mTOR pathway in mammary glands of pubescent mice, increased the secretion of insulin-like growth factor 1 (IGF-1) and estradiol (E2), and then stimulated mammary gland ductal development. Whereas a high concentration of NaHS $(18 \mathrm{mg} / \mathrm{kg})$ elicited the opposite effects to those of low-dose NaHS. In conclusion, the present study demonstrated that exogenous $\mathrm{H}_{2} \mathrm{~S}$ supplied by NaHS may exert bidirectional effects on mammary gland ductal development; promoting ductal development at a low concentration and inhibiting it at a high concentration. The effects of $\mathrm{H}_{2} \mathrm{~S}$ may occur via the intracellular PI3K/Akt-mTOR signaling pathway, or by regulation of the secretion of IGF-1 and E2.

\section{Introduction}

The mammary gland is specific to mammals, and serves to produce milk as a source of nutrition and immune factors for offspring (1). Periodic changes in the structure and function of the mammary gland occur throughout the life of female mammals; ductal development occurs primarily in puberty and is vital for pregnancy and lactation $(2,3)$. Ductal elongation occurs rapidly at the onset of puberty and terminal end buds are repositioned to the ductal termini and invade through the fat pad to form the ductal tree (4). The ductal system is the result of the concerted actions of growth hormones, estrogen and insulin-like growth factor 1 (IGF-1) $(5,6)$. Puberty is also the developmental point where diet has the most profound influence on ductal development $(7,8)$. For example, either protein- $(9)$ or energy-based $(10,11)$ diets can adversely affect mammary gland development.

Notably, environmental factors, such as heat stress (12) or $\mathrm{H}_{2} \mathrm{~S}$ (13), have been reported to exhibit restrictive effects on the development of the mammary gland duct. Furthermore, the phosphatidylinositol 3-kinase/protein kinase B (PI3K/Akt) signaling pathway has an important role in mammary gland development (10) and in cell proliferation by regulating the 
expression of proteins that mediate $\mathrm{G}_{1}$-phase to $\mathrm{S}$-phase transition in the cell cycle (5). Additionally, the mammalian target of rapamycin (mTOR) signaling pathway has been reported to participate in the regulation of mammary gland biochemical changes (14), milk protein synthesis in bovine mammary epithelial cells (15), and cell proliferation of bovine mammary epithelial cells and porcine mammary gland epithelial cells $(13,16)$.

In the cell cycle, cyclin $\mathrm{D}$ and cyclin $\mathrm{E}$ are required for transition from the $G_{1}$ phase to the $S$ phase. During the $S$ phase, cyclin A has been reported to be involved in the initiation and completion of DNA replication (17). Proliferating cell nuclear antigen (PCNA) is considered an essential component for DNA replication (18). In addition, p21 is regarded as a potent, tight-binding inhibitor of cyclin-dependent kinase (19). It had been reported that different fatty acids may regulate the proliferation of $\mathrm{HC} 11$ cells and mammary gland development of pubescent mice through modulating the protein and gene expression levels of cyclin D1 and p21 $(10,20,21)$.

Our previous study examined the effects of the endogenous signaling molecule $\mathrm{H}_{2} \mathrm{~S}$ on the proliferation of mammary cells in culture. It was demonstrated that proliferation of porcine mammary epithelial cells cultured with the $\mathrm{H}_{2} \mathrm{~S}$ donor sodium hydrosulfide (NaHS) at $10 \mu \mathrm{M}$ was stimulatory, whereas proliferation of cells cultured at $600 \mu \mathrm{M}$ NaHS was inhibitory (13). $\mathrm{H}_{2} \mathrm{~S}$ is a gaseous signaling molecule that is synthesized in vivo and influences normal cellular physiological processes, including cellular proliferation and differentiation $(22,23)$, cytoprotection $(24)$, and protection of the cardiovascular or nervous system (25). $\mathrm{H}_{2} \mathrm{~S}$ has been reported to be a regulator of numerous signaling pathways, including the ERK1/2 (26), JAK/STAT (27), Nrf2 (28), mTOR (29) and PI3K/Akt (30) signaling pathways. In addition, our previous study revealed that $\mathrm{H}_{2} \mathrm{~S}$ affected cultured mammary cell proliferation by regulating the phosphorylation of key factors involved in mammary gland development in animals via the PI3K/Akt-mTOR signaling pathway (13). Thus, the present study was designed to investigate the effects of exogenous $\mathrm{H}_{2} \mathrm{~S}$, provided by NaHS, on the mammary development of pubescent mice. Furthermore, the contributions of the intracellular PI3K/Akt-mTOR signaling pathway, IGF-1 and estradiol (E2) in this process were investigated.

\section{Materials and methods}

Reagents. NaHS was obtained from Sigma-Aldrich; Merck KGaA. RPMI-1640 medium, high glucose (HG)-DMEM and fetal bovine serum (FBS) were purchased from Gibco; Thermo Fisher Scientific, Inc. Cell Counting Kit-8 (CCK-8) was purchased from Dojindo Molecular Technologies, Inc. Cell-Light EdU in vitro kit was purchased from Guangzhou Ribobio Co.Ltd. Cyclin D1 was identified using a rabbit monoclonal antibody against cyclin D1 (cat. no. 2922S; Cell Signaling Technology, Inc.), PCNA was identified using a mouse monoclonal antibody against PCNA (cat. no. 2586; Cell Signaling Technology, Inc.), p21 was targeted using a rabbit monoclonal antibody against p21 (cat. no. 2947; Cell Signaling Technology, Inc.), phosphorylated (p)-Akt ${ }_{\text {Ser473 }}$ and Akt were targeted with rabbit monoclonal antibodies against $\mathrm{p}-\mathrm{Akt}_{\mathrm{Ser} 43}$ and $\mathrm{Akt}$ (cat. nos. 4060 and 4691; Cell Signaling Technology, Inc.),
p-mTOR ${ }_{\text {Ser2448 }}$ and mTOR were targeted with rabbit monoclonal antibodies against p-mTOR ${ }_{\text {Ser2448 }}$ and mTOR (cat. nos. 5536 and 2983; Cell Signaling Technology, Inc.), p-PI3K $\mathrm{K}_{\text {Tyr508 }}$ was targeted with a goat polyclonal antibody against $\mathrm{p}-\mathrm{PI} 3 \mathrm{~K}_{\mathrm{Ty} 508}$ (cat. no. sc-12929; Santa Cruz Biotechnology, Inc.), PI3K was targeted with a rabbit polyclonal antibody against PI3K (cat. no. bs-0128R; BIOSS), p-JAK $2_{\text {Tyr1007/Tyr1008 }}$ and $\beta$-actin were targeted with rabbit polyclonal antibodies against p-JAK2 Tyr1007/Tyr1008 and $\beta$-actin (cat. nos. bs-2485R and bs-0061R; BIOSS), p-STAT5 $5_{\text {Tyr694 }}$ was targeted with a rabbit monoclonal antibody against p-STAT5 ${ }_{\text {Tyr694 }}$ (cat. no. ab32364; Abcam), JAK2 was targeted with a rabbit monoclonal antibody against JAK2 (cat. no. 3230; Cell Signaling Technology, Inc.), STAT5 was targeted with a rabbit polyclonal antibody against STAT5 (cat. no. 9363S; Cell Signaling Technology Inc.) and IGF-1 was targeted with a rabbit monoclonal antibody against IGF-1 (cat. no. 28530-1-AP; ProteinTech Group, Inc.). Primary antibodies Cyclin D1, p21, p-Akt ${ }_{\text {Ser473 }}$, Akt, p-mTOR Ser2448 $_{\text {mTOR, }}$ PI3K, p-JAK2 Tyr1007/Tyr1008 , JAK2, p-STAT5 ${ }_{\text {Tyr694 }}$, STAT5, IGF-1 and $\beta$-actin were conjugated with goat anti-rabbit secondary antibody (cat. no. bs-0295G; BIOSS), PCNA was conjugated with goat anti-mouse secondary antibody (cat. no. bs-0296G; BIOSS) and p-PI3K $\mathrm{T}_{\mathrm{Ty} 508}$ was conjugated with donkey anti-goat secondary antibody (cat. no. bs-0294D; BIOSS).

Cell preparation and culture. Due to the convenience of obtaining materials in the laboratory, pig primary cell culture was chosen instead of the previously used mice studies. Sow ovaries were obtained from Foshan Food Co. Ltd. Meat United Processing Factory and primary granulosa cells (GCs) were isolated as previously described (31). Briefly, follicles with a glossy appearance that lacked a corpus luteum and appeared normal were placed in PBS containing $1 \mathrm{X}$ penicillin-streptomycin (pen/strep) and transported to the laboratory quickly for isolation. The follicular fluid was extracted by superficial insertion of a 1-ml sterile syringe into ovarian antral follicles, and follicular fluid was centrifuged at $105 \mathrm{x} \mathrm{g}$ at $4^{\circ} \mathrm{C}$ for $6 \mathrm{~min}$ in a centrifuge tube containing $5 \mathrm{ml}$ HG-DMEM. The cells were cultured with HG-DMEM/10\% FBS and 1\% pen/strep. The cells obtained from 10 pairs of ovaries were seeded in a flask at $37^{\circ} \mathrm{C}$ for $24 \mathrm{~h}$ in an atmosphere containing $5 \% \mathrm{CO}_{2}$. Adherent cells were cultured in fresh medium. When cells reached $90 \%$ confluence, they were passaged using $0.25 \%$ trypsin for subsequent experiments.

The mouse mammary epithelial cell line HC11 (cat. no. SCSP-5037; The Cell Bank of Type Culture Collection of the Chinese Academy of Sciences) were maintained in RPMI-1640 supplemented with 10\% FBS and pen/strep at $37^{\circ} \mathrm{C}$ with $5 \% \mathrm{CO}_{2}$ for $24 \mathrm{~h}$. The liver cancer cell line HepG2 (cat. no HB-8065; American Type Culture Collection) was maintained in HG-DMEM supplemented with $10 \%$ FBS and pen/strep at $37^{\circ} \mathrm{C}$ with $5 \% \mathrm{CO}_{2}$ for $24 \mathrm{~h}$.

Cell treatments. HC11 cells in RPMI-1640 supplemented with $10 \% \mathrm{FBS}$ and pen/strep were cultured in the presence of NaHS at $0,25,50,100,250,500,750$ or $1,000 \mu \mathrm{M}$ for 4 days at $37^{\circ} \mathrm{C}$. HepG2 cells $\left(4 \times 10^{5} /\right.$ well) and GCs $\left(1 \times 10^{6} /\right.$ well) were separately inoculated in 6-well plates, and cultured in HG-DMEM supplemented with 10\% FBS and pen/strep, 
followed by treatment with $0,10,100$ or $600 \mu \mathrm{M}$ NaHS at $37^{\circ} \mathrm{C}$ for $24 \mathrm{~h}$.

Cell viability was assessed with HC11 cells in 96-well plates at a density of $8 \times 10^{3}$ cells/well in replicates of eight. The cells were cultured in RPMI-1640 medium in the presence or absence of NaHS for 4 days. Cell viability was measured using CCK-8 assay, according to the manufacturer's protocol, and the absorbance was measured at $450 \mathrm{~nm}$.

In addition, cells were cultured in a similar manner and EdU incorporation was used to assess number of EdU-positive cells, as described previously (10). Briefly, 8x10 ${ }^{3} \mathrm{HC} 11$ cells were treated with NaHS for 4 days and exposed to EdU for $2 \mathrm{~h}$ at $37^{\circ} \mathrm{C}$. Subsequently, the plate was processed using $4 \%$ paraformaldehyde for $30 \mathrm{~min}$ at $25^{\circ} \mathrm{C}$ and the Cell-Light EdU in vitro kit containing the nuclear dye Hoechst 33342 was used, according to the manufacturer's protocol. Images of the cells were captured using a Nikon Eclipse Ti-s fluorescent microscope (Nikon Corporation).

Animals and samples. The animal experiments performed in the present study were approved by the Ethics Committee of South China Agricultural University (approval no. SYXK2014-0136). Care of all animals and procedures at South China Agricultural University were confirmed to 'The Instructive Notions with Respect to Caring for Laboratory Animals' issued by the Ministry of Science and Technology of the People's Republic of China, and were approved by the Animal Subjects Committee of South China Agricultural University (Guangzhou, China). A total of $48 \mathrm{C} 57 \mathrm{BL} / 6$ female mice (3 weeks old, 15 $\pm 0.08 \mathrm{~g}$ ) were purchased from Guangdong Medical Laboratory Animal Center and acclimated for 1 week in laboratory housing prior to the experiments. The mice were divided into four groups: i) Control, which received intraperitoneal injections of saline; ii) intraperitoneal injections of $3 \mathrm{mg} / \mathrm{kg} \mathrm{NaHS}$; iii) intraperitoneal injections of $9 \mathrm{mg} / \mathrm{kg} \mathrm{NaHS}$; and iv) intraperitoneal injections of $18 \mathrm{mg} / \mathrm{kg} \mathrm{NaHS}$. All intraperitoneal injections were administered every 2 days for 4 weeks. The mice were housed at $25 \pm 1^{\circ} \mathrm{C}$ under a $12 \mathrm{~h}$ light/dark cycle and $60 \%$ humidity, with ad libitum access to food and water. At the end of the experiments, the animals were euthanized with $\mathrm{CO}_{2}$. Animals were placed into chambers and a flow rate of $16 \%$ chamber volume/min was used until the mouse was unconscious. Gas flow was maintained for at least $1 \mathrm{~min}$ following apparent clinical death. Death was verified by the absence of a heartbeat, performing cervical dislocation and by perforating the diaphragm. Blood samples were collected from the orbital sinus after euthanasia and serum was separated by centrifugation at $1,500 \mathrm{xg}$ for $20 \mathrm{~min}$ prior to storage at $-20^{\circ} \mathrm{C}$. The fourth pairs of mammary glands were excised and used as samples for subsequent experiments. The mammary samples were weighed immediately. The right side of the sample, as well as the livers, were stored at $-80^{\circ} \mathrm{C}$ for later analyses. The left side of the sample was collected and stained with whole mount and $\mathrm{H} \& \mathrm{E}$ as described previously (10) and was quantified as described previously (32). Livers were homogenized according to previously described methods (33).

Reverse transcription-quantitative PCR (RT-qPCR). mRNA expression levels of cyclin D1, PCNA and cyclin D3 were measured using RT-qPCR, according to previously described methods (34). Briefly, total RNA was extracted from HC11 cells and mammary gland samples using an RNA extraction kit (Guangzhou Magen Biotechnology Co. Ltd., according to the manufacturer's protocol. Subsequently, cDNA was synthesized from $2 \mu \mathrm{g}$ total RNA using the M-MLV Reverse Transcriptase (Promega Corporation) and random primers oligo-(dT)18 (cat. no. 3806; Takara Biotechnology Co., Ltd.), according to the manufacturer's instructions. $\beta$-actin was used as a candidate housekeeping gene. RT-qPCR was carried out on an Mx3005p instrument (Stratagene; Agilent Technologies, Inc.,) using SYBR ${ }^{\circledR}$ Green Real-time PCR Master Mix reagents (Toyobo Life Science). The thermocycling conditions were as follows: $15 \mathrm{sec}$ at $95^{\circ} \mathrm{C}$ for denaturing, $15 \mathrm{sec}$ at $55-62^{\circ} \mathrm{C}$ for annealing and $40 \mathrm{sec}$ at $72^{\circ} \mathrm{C}$ for extension (40 cycles). In the last cycle, the conditions were as follows: $60 \mathrm{sec}$ at $95^{\circ} \mathrm{C}$ for denaturing, $30 \mathrm{sec}$ at $55-62^{\circ} \mathrm{C}$ for annealing and $30 \mathrm{sec}$ at $95^{\circ} \mathrm{C}$ for extension. Primer sequences with their respective PCR fragment lengths are presented in Table I.

Western blot analysis. Expression levels of total and phosphorylated proteins were assessed by western blot analysis, according to previously described methods (10). Proteins from HC11 cells and mammary glands were extracted with RIPA lysis buffer (Shanghai BestBio Co. Ltd.) containing $1 \mathrm{mM}$ PMSF (cat. no. P0100; Beijing Solarbio Science \& Technology Co. Ltd.). Protein concentration was determined using a BCA protein assays (cat. no. 23225; Thermo Fisher Scientific, Inc.). Equivalent amounts of protein $(20 \mu \mathrm{g})$ were separated by $10 \%$ SDS PAGE and the samples were transferred onto nitrocellulose membranes (BioRad Laboratories, Inc.). Membranes were then subjected to immunoblotting with rabbit anti-cyclin D1 $(1: 2,000)$, mouse anti-PCNA $(1: 2,000)$, rabbit anti-p21 $(1: 2,000)$, rabbit anti-Akt $(1: 2,000)$, rabbit anti-p-Akt $\mathrm{Aer}_{\mathrm{S} 73}$ $(1: 2,000)$, rabbit anti-PI3K $(1: 2,000)$, goat anti-p-PI3K $\mathrm{K}_{\mathrm{Ty} 508}$ $(1: 800)$, rabbit anti-mTOR $(1: 2,000)$, rabbit anti-p-mTOR Ser2448 (1:2,000), rabbit anti-IGF-1 (1:1,000), rabbit anti-JAK2 $(1: 1,000)$, rabbit anti-p-JAK2 $(1: 1,000)$, rabbit anti-STAT5 $(1: 1,000)$, rabbit anti-p-STAT5 $(1: 1,000)$ and rabbit anti- $\beta$-actin $(1: 1,000)$ diluted in $0.05 \%$ TBS-Tween-20 (TBST) overnight at $4^{\circ} \mathrm{C}$, followed by incubation at room temperature for $1 \mathrm{~h}$ with donkey anti-goat, goat anti-rabbit and goat anti-mouse $(1: 10,000)$ secondary antibodies diluted in TBST, as required. Western blots were visualized using Super Signal West Pico Chemiluminescence substrate (Thermo Fisher Scientific, Inc.) and semi-quantified with ImageJ software (version 1.4.3.67; National Institutes of Health).

Radioimmunoassay. The IGF-1 and E2 radioimmunoassay kits (cat. nos. RF6 and RG6) were purchased from Jiuding Medical Biological Engineering Co., Ltd. Mice serum and cell culture supernatant IGF-1 and E2 concentrations were measured by GC-1200 Gamma RIA counter (Anhui Zhongke Zhongjia Scientific Instruments, Co., Ltd.) according to the manufacturer's recommendation.

Statistical analysis. Data are presented as the mean \pm standard error of the mean. One-way ANOVA with a Dunnett's post hoc test were applied for statistical analyses of the data using Sigma Plot 12.5 software (Systat Software, Inc.). $\mathrm{P}<0.05$ was considered to indicate a statistically significant difference. 
Table I. Primer sequences used for reverse transcription-quantitative PCR.

\begin{tabular}{lllc}
\hline Gene & \multicolumn{1}{c}{ Forward (5'-3') } & \multicolumn{1}{c}{ Reverse (5'-3') } & Amplification length (bp) \\
\hline Cyclin D1 & CTGAAGGCTCGCGGAATAAAA & GAGGTCTTTACGGATGTCAACG & 142 \\
Cyclin D3 & CGAGCCTCCTACTTCCAGTG & GGACAGGTAGCGATCCAGGT & 150 \\
PCNA & TTTGAGGCACGCCTGATCC & GGAGACGTGAGACGAGTCCAT & 135 \\
$\beta$-actin & GGTCATCACTATTGGCAACGAG & TGATCTCCTTCTGCATCCTGT & 131 \\
\hline
\end{tabular}

bp, base pairs; PCNA, proliferating cell nuclear antigen.

A

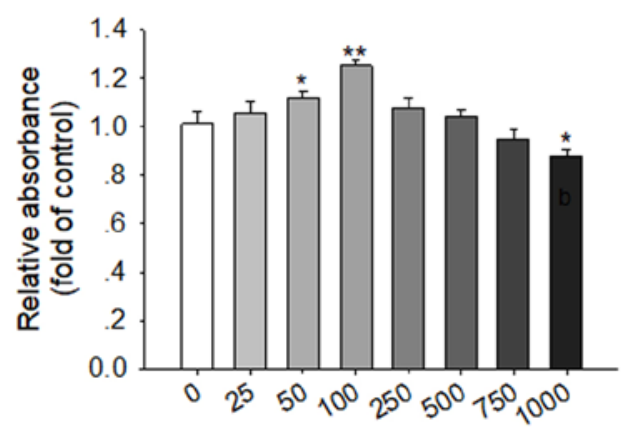

$\operatorname{NaHS}(\mu \mathrm{M})$

D

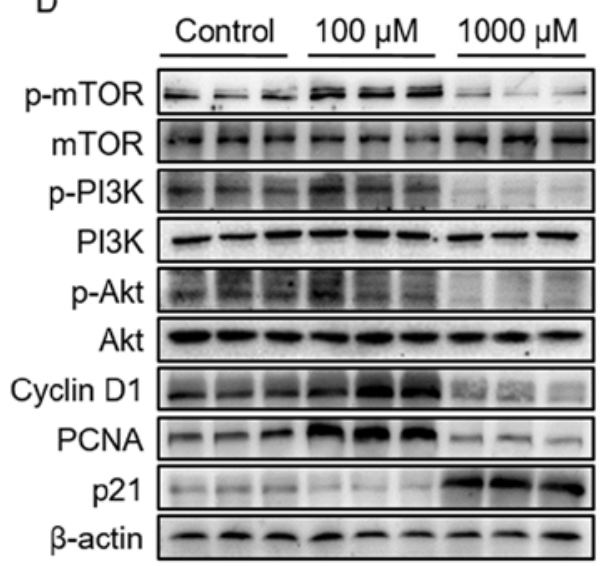

B

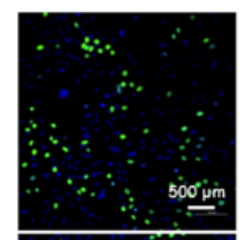

C

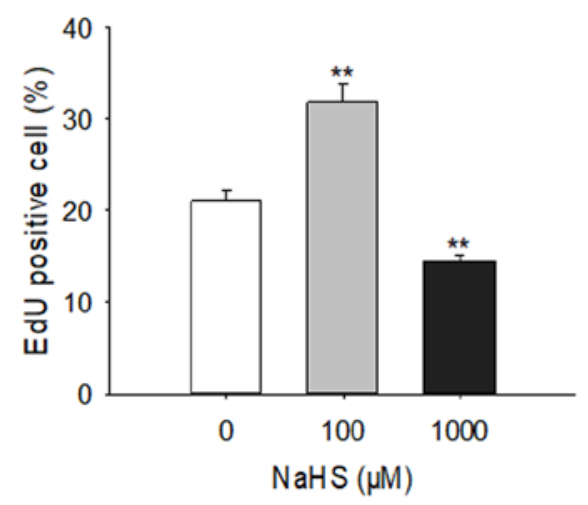

$\mathrm{F}$

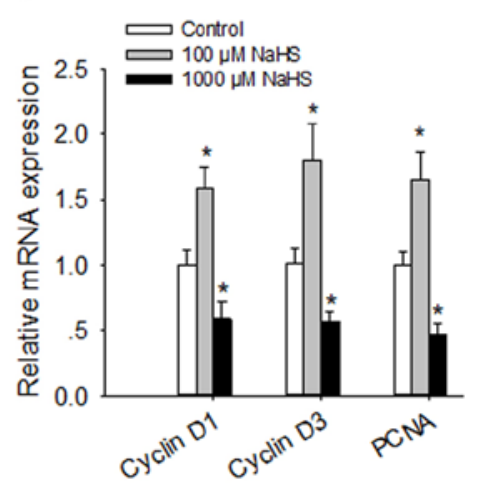

Figure 1. Effects of NaHS on HC11 cell viability and the PI3K/Akt-mTOR signaling pathway. HC11 cells were cultured with the indicated concentrations of NaHS for 4 days. Cell viability was evaluated by (A) CCK-8 assay and (B) EdU incorporation. Blue indicated nuclei and green indicated EdU-positive. (C) Analysis of the percentage of EdU-positive cells. (D) Western blot analysis of $\mathrm{HC} 11$ cell extracts following exposure to 0,100 and 1,000 $\mu \mathrm{M}$ NaHS for 4 days. Blots were developed using antibodies raised against cyclin D1, PCNA, p21, p-PI3K, p-Akt, p-mTOR, PI3K, Akt and mTOR. $\beta$-actin was used as loading control. (E) Intensities of the western blot bands were semi-quantified and presented as the mean \pm standard error of the mean of three replicates. (F) Reverse transcription-quantitative PCR analysis of the indicated genes expressed in HC11 cells exposed to NaHS. mRNA expression levels are expressed relative to the internal control gene $\beta$-actin. ${ }^{*} \mathrm{P}<0.05,{ }^{* *} \mathrm{P}<0.01$ vs. control group. NaHS, sodium hydrosulfide; PCNA, proliferating cell nuclear antigen; p-, phosphorylated; PI3K, phosphatidylinositol 3-kinase; Akt, protein kinase B; mTOR, mammalian target of rapamycin.

\section{Results}

In vitro effects of NaHS on cell viability. HC11 cells were treated with different concentrations $(0,25,50,100,250$, $500,750$ or $1,000 \mu \mathrm{M})$ of the $\mathrm{H}_{2} \mathrm{~S}$ donor NaHS for 4 days to determine the concentration that enhanced viability. It was identified that treatment with either 50 or $100 \mu \mathrm{M}$ NaHS significantly promoted $\mathrm{HC} 11$ cell viability, whereas treatment with $1,000 \mu \mathrm{M}$ significantly inhibited viability (Fig. 1A). This result was also reflected by the increased number of EdU-positive cells exposed to NaHS at $100 \mu \mathrm{M}$, whereas the proportion of these cells was significantly decreased at $1,000 \mu \mathrm{M}$ (Fig. 1B and C). Furthermore, cyclin D1 and PCNA protein expression levels were significantly increased, whereas p21 expression levels were significantly reduced in cells treated with $100 \mu \mathrm{M}$ NaHS compared with the untreated controls. By contrast, when treated with $1,000 \mu \mathrm{M}$ NaHS, the opposite effects were observed on cyclin D1, PCNA and p21 expression 
A

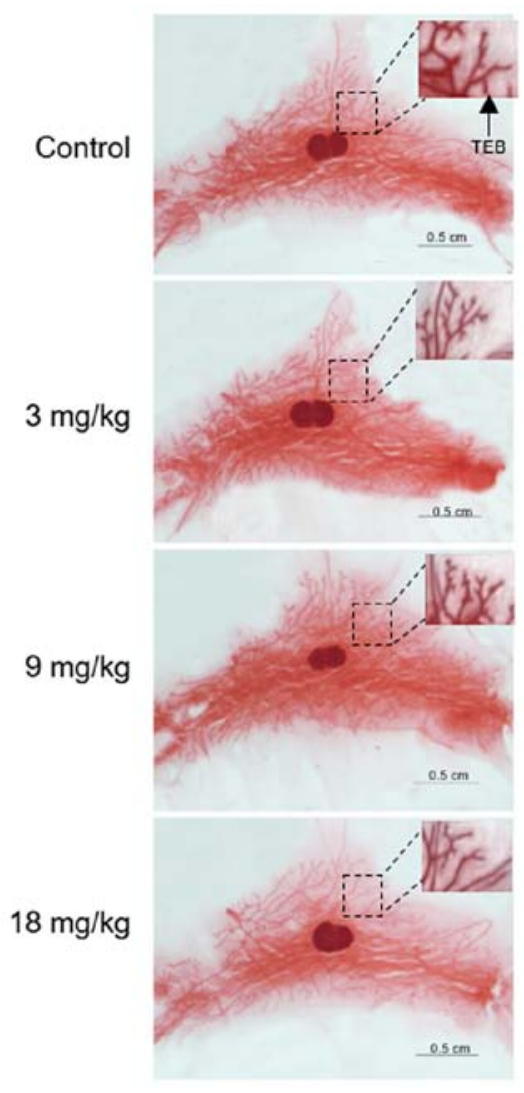

B

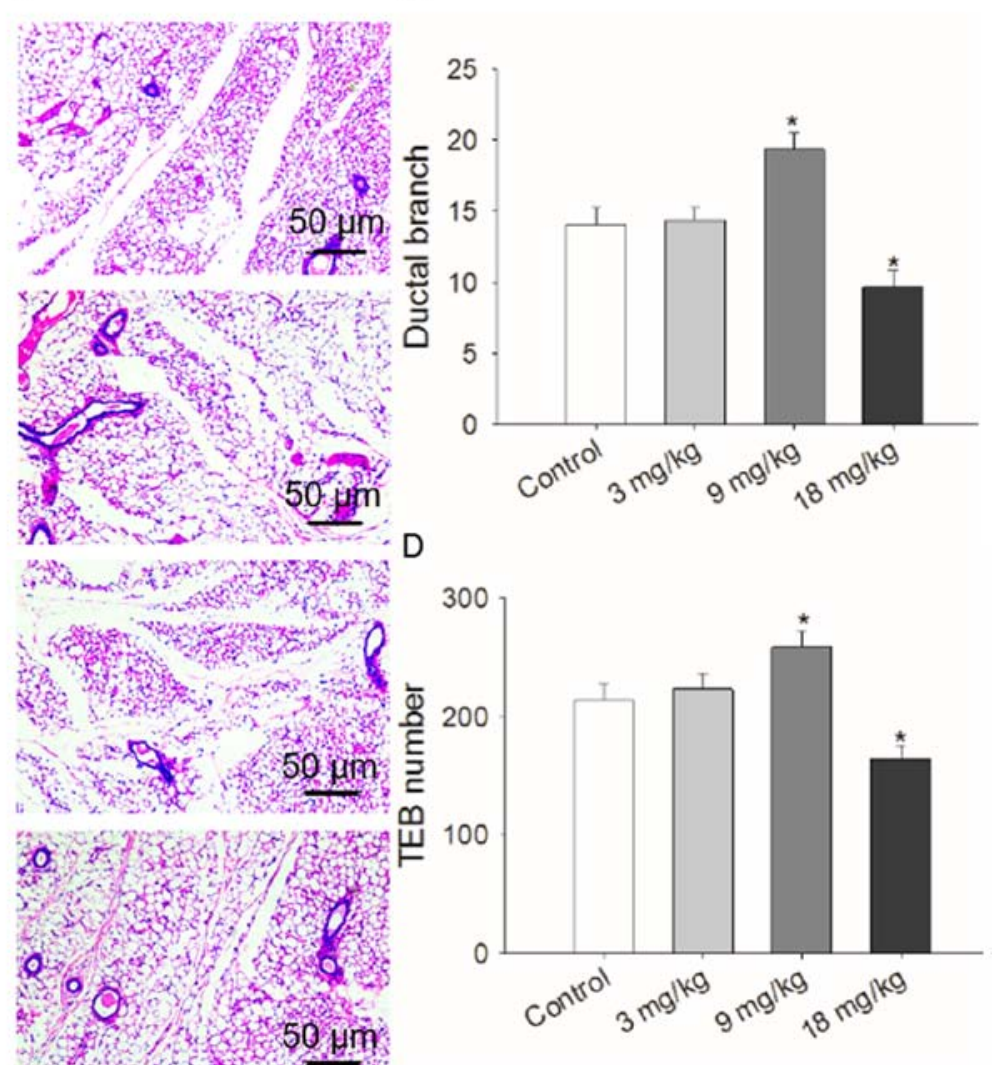

Figure 2. Exogenous $\mathrm{H}_{2} \mathrm{~S}$ regulates mammary ductal growth of prepubescent mice. C57BL/6 female mice were exposed to NaHS for 4 weeks at the indicated doses ( $n=12$ /group). Representative images of (A) whole mount and (B) H\&E staining of the fourth pair of mouse mammary glands. The arrow indicates TEBs. Quantification of (C) TEB and (D) ductal branches $(n=6)$. ${ }^{*}<<0.05$ vs. control group. NaHS, sodium hydrosulfide; TEB, terminal end buds.

levels (Fig. 1D and E). Corroborating these results, the mRNA expression levels of PCNA, cyclin D3 and cyclin D1 were significantly increased by $100 \mu \mathrm{M}$ NaHS, whereas $1,000 \mu \mathrm{M}$ NaHS resulted in the opposite effect (Fig. 1F).

The effects of NaHS treatment on the signaling pathways associated with proliferation were also examined. It was demonstrated that $100 \mu \mathrm{M}$ NaHS activated in the phosphorylation of mTOR, PI3K and Akt, whereas 1,000 $\mu \mathrm{M}$ NaHS significantly inhibited the phosphorylation of these proteins compared with the untreated control (Fig. 1D and E).

In vivo effects of NaHS on prepubescent mammary development. Prepubescent female mice were exposed to differing treatment concentrations of NaHS via intraperitoneal injection and ductal development was examined over 4 weeks. The number of ductal branches observed in whole mounts of mammary tissue samples was significantly increased in the mice that received $9 \mathrm{mg} / \mathrm{kg} \mathrm{NaHS}$, whereas opposing results were seen in the mice treated with $18 \mathrm{mg} / \mathrm{kg}$. The lowest level of NaHS used $(3 \mathrm{mg} / \mathrm{kg}$ ) did not result in a significant difference (Fig. 2A and C). Similar to the results of whole mount staining, H\&E staining of mammary tissues demonstrated that the number of terminal end buds was also significantly increased at $9 \mathrm{mg} / \mathrm{kg} \mathrm{NaHS}$, decreased at $18 \mathrm{mg} / \mathrm{kg}$, and was not significantly affected at $3 \mathrm{mg} / \mathrm{kg} \mathrm{NaHS}$ compared with in the control group (Fig. 2B and D). Notably, when the expression levels of mammary gland developmental proteins were examined in the prepubescent mice, treatment with 3 and $9 \mathrm{mg} / \mathrm{kg}$ NaHS significantly promoted PCNA and cyclin D1 expression, as well as the phosphorylation of mTOR, PI3K and Akt compared with in the control group. By contrast, $18 \mathrm{mg} / \mathrm{kg} \mathrm{NaHS}$ significantly inhibited cyclin D1 and PCNA expression, as well as the phosphorylation of PI3K, Akt and mTOR (Fig. 3A and B). The mRNA expression levels of PCNA and cyclin D1 were also enhanced following treatment with $9 \mathrm{mg} / \mathrm{kg} \mathrm{NaHS}$ (Fig. 3C).

$\mathrm{H}_{2} \mathrm{~S}$ affects IGF-1 production. The expression levels of IGF-1 were subsequently detected in the serum and livers of $\mathrm{H}_{2} \mathrm{~S}$-treated animals, which revealed that the amount of IGF-1 in the serum was significantly increased by exposure to $9 \mathrm{mg} / \mathrm{kg}$ $\mathrm{NaHS}$, whereas the levels were significantly reduced with $18 \mathrm{mg} / \mathrm{kg} \mathrm{NaHS}$ (Fig. 4A). In addition, IGF-1 expression, and the phosphorylation of JAK2 and STAT5, were significantly increased in liver tissues of the mice treated with 3 or $9 \mathrm{mg} / \mathrm{kg}$ NaHS compared with in the control group. By contrast, a dose of $18 \mathrm{mg} / \mathrm{kg}$ NaHS significantly inhibited IGF-1 expression, and JAK2 and STAT5 phosphorylation (Fig. 4B and C). Furthermore, the mRNA expression levels of IGF-1 were significantly higher in the livers of the $9 \mathrm{mg} / \mathrm{kg}$-treated mice compared with the untreated controls (Fig. 4D).

IGF-1 is mainly synthesized and secreted by the liver (35); therefore, the present study used HepG2 as a model to study whether exogenous $\mathrm{H}_{2} \mathrm{~S}$ affected the development of the 


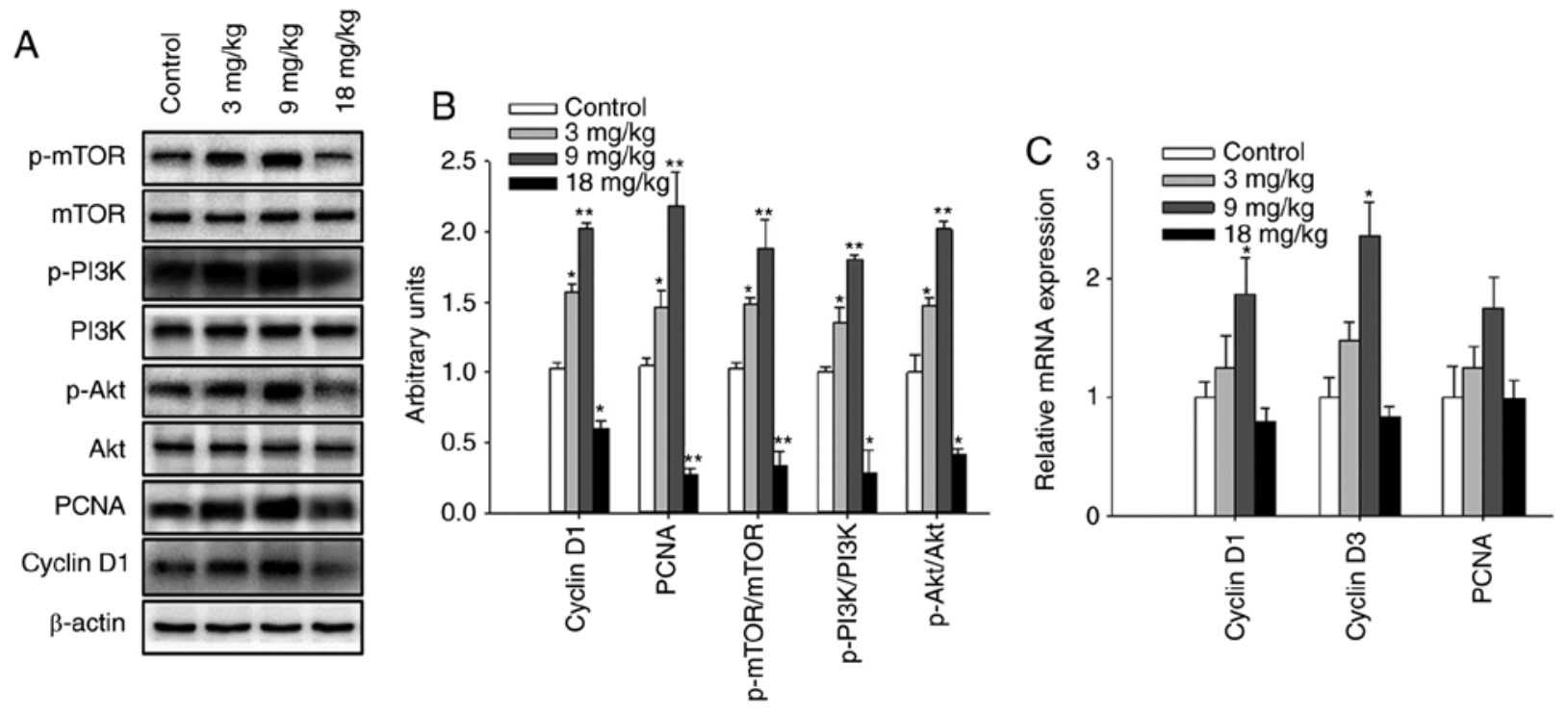

Figure 3. Exogenous $\mathrm{H}_{2} \mathrm{~S}$ modulates mammary gland development. Mice were exposed to NaHS and tissue samples were processed after 4 weeks of exposure $(\mathrm{n}=4)$. (A) Western blot analysis of the indicated proteins in tissue samples. (B) Semi-quantification of western blotting. (C) mRNA expression levels of PCNA, cyclin D1 and cyclin D3 from total RNA extracted from mammary glands $(n=6) .{ }^{*} \mathrm{P}<0.05,{ }^{* *} \mathrm{P}<0.01$ vs. control group. NaHS, sodium hydrosulfide; PCNA, proliferating cell nuclear antigen; p-, phosphorylated; PI3K, phosphatidylinositol 3-kinase; Akt, protein kinase B; mTOR, mammalian target of rapamycin.

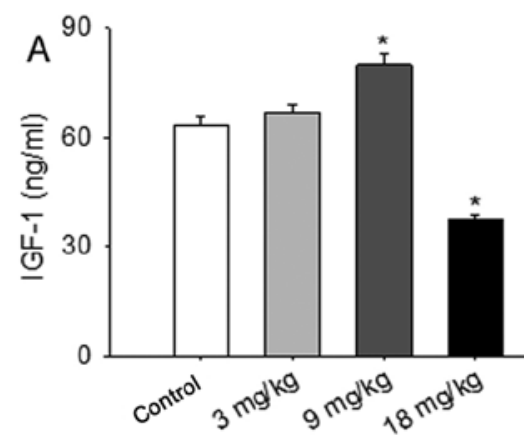

B

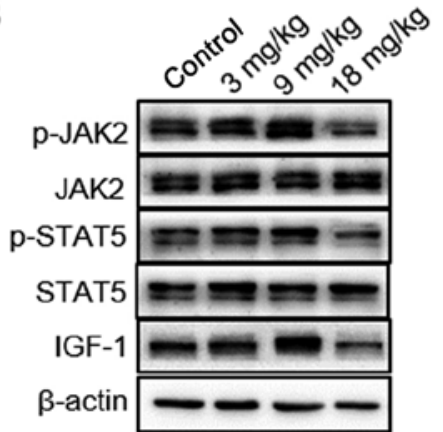

$E$

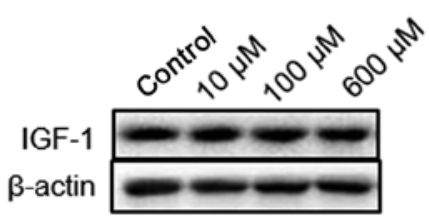

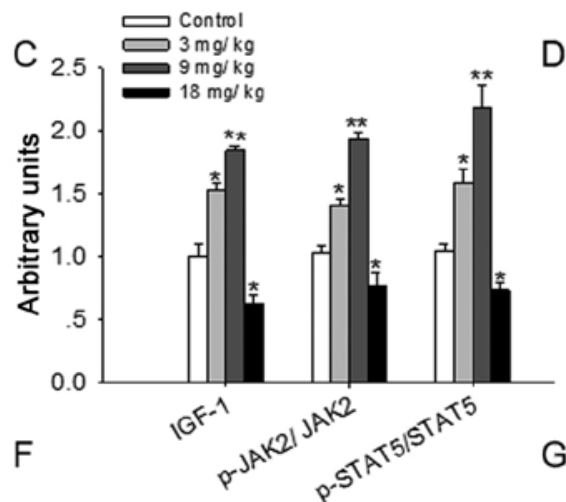
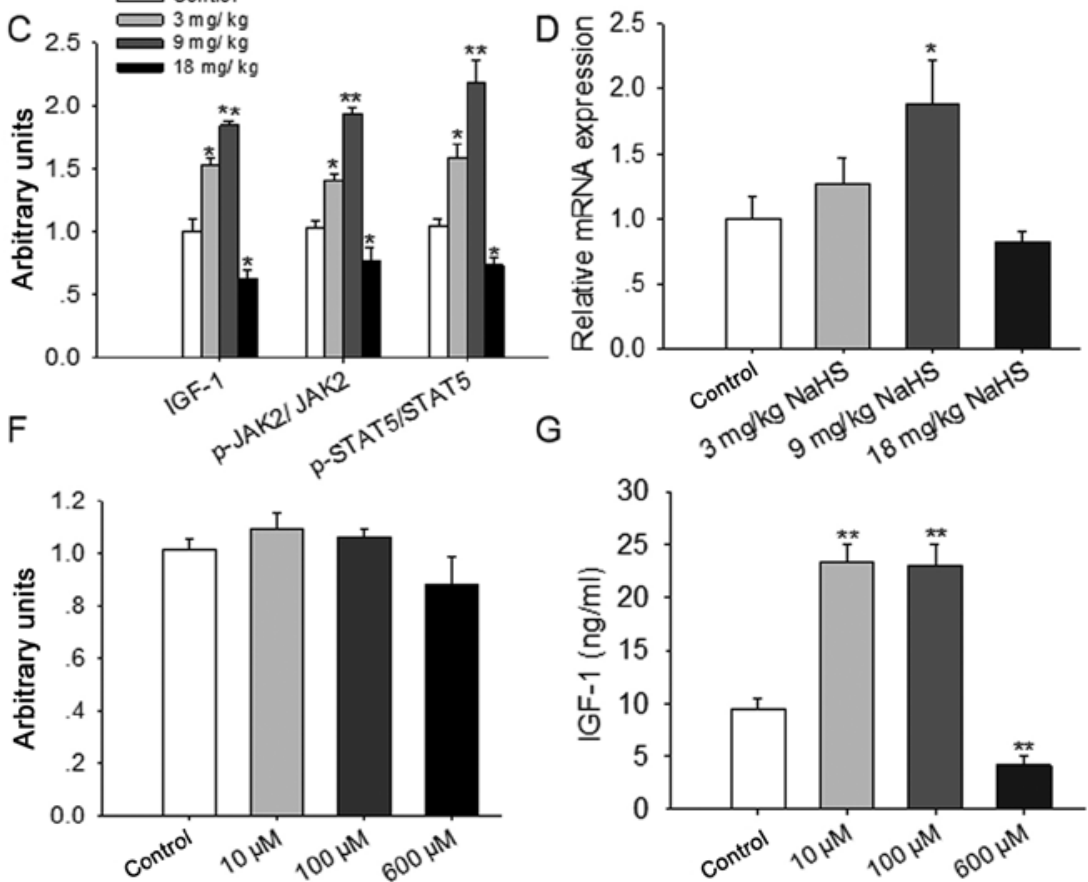

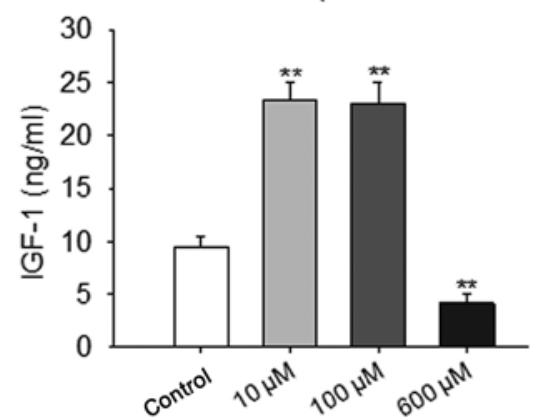

Figure 4. Effects of exogenous $\mathrm{H}_{2} \mathrm{~S}$ on the secretion and expression of IGF-1. Mice were exposed to NaHS for 4 weeks. (A) Serum IGF levels. (B) Western blot analysis of the indicated proteins in total mouse liver extracts $(n=4)$. (C) Densitometric analysis of the western blots. (D) mRNA expression levels of IGF-1 in liver samples ( $\mathrm{n}=6$ ). (E) Western blot analysis of IGF-1 in HepG2 cells treated with $0,10,100$ and $600 \mu \mathrm{M} \mathrm{NaHS}$ for $24 \mathrm{~h}$ (n=3). (F) Densitometric analysis of IGF-1 protein expression levels. (G) IGF-1 levels in the culture medium of HepG2 cells exposed to the indicated concentrations of NaHS for $24 \mathrm{~h}$. "P<0.05, ${ }^{* *} \mathrm{P}<0.01$ vs. control group. NaHS, sodium hydrosulfide; IGF-1, insulin-like growth factor 1; p-, phosphorylated. 

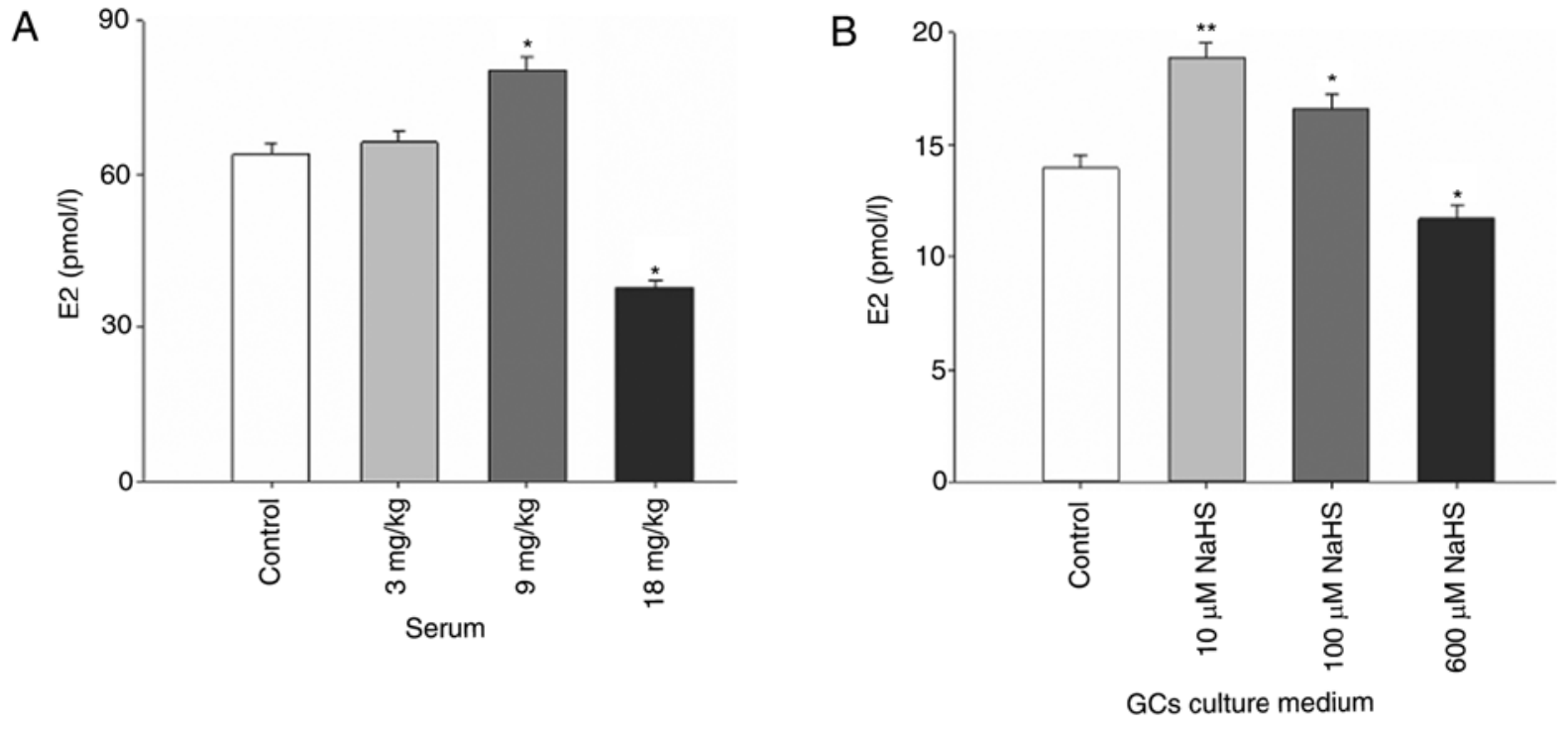

Figure 5. Effects of exogenous $\mathrm{H}_{2} \mathrm{~S}$ on E2 secretion. Mice were treated with NaHS for 4 weeks. (A) Serum E2 levels in mice in the indicated treatment groups. (B) E2 levels in primary cultures of sow ovarian GCs treated with $0,10,100$ and $600 \mu \mathrm{M}$ NaHS for $24 \mathrm{~h} .{ }^{*} \mathrm{P}<0.05,{ }^{* * *} \mathrm{P}<0.01$ vs. control group. E2, estradiol; NaHS, sodium hydrosulfide; GCs, granulosa cells.

mammary gland through the synthesis and secretion of IGF-1. Consequently, the liver-associated effects of NaHS on IGF-1 expression were examined using the HepG2 cell line, which was treated with $0,10,100$ or $600 \mu \mathrm{M}$ NaHS for $24 \mathrm{~h}$. No significant effects of NaHS on IGF-1 protein expression levels in HepG2 cell extracts were observed (Fig. 4E and F). However, significantly increased levels of IGF-1 were identified in the cell culture medium following treatment with either 10 or $100 \mu \mathrm{M} \mathrm{NaHS}$, whereas the expression levels of IGF-1 were significantly decreased in the $600 \mu \mathrm{M}$ NaHS-treated group (Fig. 4G).

$\mathrm{H}_{2} \mathrm{~S}$ affects $\mathrm{E} 2$ production. E2 is a key regulator of the advancement to puberty in mammals (36). Therefore, the present study examined whether serum E2 levels were altered in mice treated with exogenous NaHS. NaHS administered at $9 \mathrm{mg} / \mathrm{kg}$ significantly increased the content of $\mathrm{E} 2$ in the serum of mice, whereas $18 \mathrm{mg} / \mathrm{kg}$ NaHS significantly reduced E2 levels (Fig. 5A). To examine this in more detail, primary cultures of sow ovarian GCs exposed to NaHS for $24 \mathrm{~h}$ were analyzed. Notably, E2 levels in cells treated with 10 and $100 \mu \mathrm{M}$ NaHS were significantly increased, whereas the expression levels of E2 were significantly decreased by treatment with $1,000 \mu \mathrm{M}$ NaHS (Fig. 5B).

\section{Discussion}

The present study demonstrated that $\mathrm{H}_{2} \mathrm{~S}$ had a major effect on mammary gland development in prepubescent female mice. Under the current additional dose condition, $9 \mathrm{mg} / \mathrm{kg}$ of NaHS that promoted the ductal and terminal end buds branch numbers in prepubescent mice were verified, which was also associated with enhanced viability of cultured $\mathrm{HC} 11$ cells. In line with the present results, it has previously been reported that $\mathrm{H}_{2} \mathrm{~S}$ exerts biphasic effects on the proliferation of porcine mammary epithelial cells (PMECs) (13). The different doses of NaHS shown to exert effects among the present and other studies may be due to the use of different cell types and culturing times. $\mathrm{H}_{2} \mathrm{~S}$ is a gaseous messenger molecule that has been implicated in various physiological and pathological processes in mammalian organs, including the brain (37), liver (38), heart (39) and other organs $(40,41)$. However, understanding the effect of $\mathrm{H}_{2} \mathrm{~S}$ on mammary gland hyperplasia requires further studies.

In order to determine the regulatory function of $\mathrm{H}_{2} \mathrm{~S}$ on HC11 cell proliferation and mammary ductal growth, the expression levels of proliferative marker genes, including cyclin D1/D3 and PCNA were detected. Accordingly, markers of cell proliferation, including cyclin D1/D3 and PCNA, were enhanced by the optimal levels of $\mathrm{H}_{2} \mathrm{~S}$. Cyclin D family of proteins is critical for the $\mathrm{G}_{1}$ to $\mathrm{S}$ transition (17), and PCNA is an associated factor known to be necessary for control of DNA replication during the S phase (42). Cyclin D1, cyclin D3 and PCNA modulate mammary gland development and mammary epithelial cell proliferation $(10,13,20)$. The present study revealed that lower doses $(100 \mu \mathrm{M})$ of NaHS increased cyclin D1, cyclin D3 and PCNA mRNA expression levels; however, these were decreased when higher doses of NaHS were used $(1,000 \mu \mathrm{M})$. Furthermore, the number of cells in the $\mathrm{S}$ phase was increased following treatment with low concentrations of $\mathrm{NaHS}$, and was decreased by high concentrations. These data suggested that $\mathrm{H}_{2} \mathrm{~S}$ may be a regulator of mammary ductal growth.

The PI3K/Akt-mTOR pathway is crucial for the regulation of proliferation of numerous cell types, such as PMECs (13), breast cancer cells (43) and human osteoblast-like cells (44). In addition, PI3K/Akt-mTOR phosphorylation has previously been associated with mammary gland development $(10,20,45)$. The results of the present study are consistent with these observations, which confirms that PI3K/Akt-mTOR signaling may be involved in $\mathrm{H}_{2} \mathrm{~S}$-indued modulation of $\mathrm{HC} 11$ cell viability and mammary gland development.

IGF-1 and E2 are both known to be critical for mammary ductal development (46). Growth hormones promote cell 
proliferation by inducing the expression of IGF-1 in the liver and mammary glands. Notably, IGF1 and E2 secreted by the ovary induce epithelial cell proliferation (47). A previous study demonstrated that IGF-1 activated the PI3K/Akt signaling pathway via its receptor and induced epithelial cell proliferation (48). Notably, these factors can also be directly controlled by dietary additions of lauric acid to increase IGF-1 and E2, which promotes mammary gland development (10), and stearic acid to decrease IGF-1 and E2, which inhibits terminal end buds and ductal branches (42). These data are consistent with the present results where intraperitoneal injection of low concentrations of NaHS $(9 \mathrm{mg} / \mathrm{kg})$ was shown to increase serum IGF-1 and E2 levels, and stimulate mammary gland ductal development. By contrast, a high concentration of NaHS $(18 \mathrm{mg} / \mathrm{kg})$ elicited the opposite effects. The expression of IGF-1 in livers of mice exposed to NaHS also agreed with the findings for serum expression levels. Notably, HepG2 and primary cultures of ovarian GCs served as models for IGF-1 and E2 secretion in response to NaHS.

In conclusion, the current results demonstrated that exogenous $\mathrm{H}_{2} \mathrm{~S}$ was able to advance mammary gland ductal development in prepubescent female mice via PI3K/Akt-mTOR signaling, and through secretion of IGF-1 and E2. These results may be beneficial for the application of $\mathrm{H}_{2} \mathrm{~S}$ in promoting or suppressing mammary gland development.

\section{Acknowledgements}

Not applicable.

\section{Funding}

This work was supported by the National Natural Science Foundation of China (grant nos. 31672508 and 31972636) and the Guangdong Special Support Program (grant no. 2014TQ01N260).

\section{Availability of data and materials}

The datasets used and/or analyzed during the current study are available from the corresponding author on reasonable request.

\section{Authors' contributions}

JZ and JY performed the experiments. SW and QJ conceptualized and designed the study. CY, QF and FZ performed the collection and analysis of the samples. XZ, LW, PG, GS and QL performed data analysis and interpretation. JZ drafted the manuscript, generated and revised the figures. QL and QJ revised the manuscript. All authors read and approved the final manuscript.

\section{Ethics approval and consent to participate}

The animal experiments performed in the present study were performed under the permission number SYXK (Guangdong) 2014-0136. Care of all animals and procedures in South China Agricultural University were confirmed to 'The Instructive Notions with Respect to Caring for Laboratory Animals' issued by the Ministry of Science and Technology of the
People's Republic of China and were approved by the Animal Subjects Committee of South China Agricultural University.

\section{Patient consent for publication}

Not applicable.

\section{Competing interests}

The authors declare that they have no competing interests.

\section{References}

1. Rezaei R, Wu Z, Hou Y, Bazer FW and Wu G: Amino acids and mammary gland development: Nutritional implications for milk production and neonatal growth. J Anim Sci Biotechnol 7: 20, 2016.

2. Hennighausen L and Robinson GW: Signaling pathways in mammary gland development. Dev Cell 1: 467-475, 2001.

3. Mcnally $\mathrm{S}$ and Stein T: Overview of mammary gland development: A comparison of mouse and human. Methods Mol Biol 1501: 1-17, 2017.

4. Visvader JE and Smith GH: Murine mammary epithelial stem cells: Discovery, function, and current status. Cold Spring Harb Perspect Biol 3: a004879, 2011.

5. Macias $\mathrm{H}$ and Hinck L: Mammary gland development. Wiley Interdiscip Rev Dev Biol 1: 533-557, 2012.

6. Brisken C and Ataca D: Endocrine hormones and local signals during the development of the mouse mammary gland. Wiley Interdiscip Rev Dev Biol 4: 181-195, 2015.

7. Hue-Beauvais C, Laubier J, Brun N, Houtia I, Jaffrezic F, Bevilacqua C, Provost FL and Charlier M: Puberty is a critical window for the impact of diet on mammary gland development in the rabbit. Dev Dyn 248: 948-960, 2019.

8. Farmer C: Review: Mammary development in swine: Effects of hormonal status, nutrition and management. Canadian J Anim Sci 93: 1-7, 2013.

9. Silva AL, Detmann E, Dijkstra J, Pedroso AM, Silva LHP, Machado AF, Sousa FC, Santos GBD and Marcondes MI: Effects of rumen-undegradable protein on intake, performance, and mammary gland development in prepubertal and pubertal dairy heifers. J Dairy Sci 101: 5991-6001, 2018.

10. Meng Y, Zhang J, Zhang F, Ai W, Zhu X, Shu G, Wang L, Gao P, Xi Q, Zhang Y, et al: Lauric acid stimulates mammary gland development of pubertal mice through activation of GPR84 and PI3K/Akt signaling pathway. J Agric Food Chem 65: 95-103, 2017.

11. Farmer C, Palin MF and Martel-Kennes Y: Impact of diet deprivation and subsequent over-allowance during prepuberty. Part 2. Effects on mammary gland development and lactation performance of sows. J Anim Sci 90: 872-880, 2012.

12. Kapila N, Sharma A, Kishore A, Sodhi M, Tripathi PK, Mohanty AK and Mukesh M: Impact of heat stress on cellular and transcriptional adaptation of mammary epithelial cells in riverine buffalo (Bubalus Bubalis). PLoS One 11: e0157237, 2016.

13. Zhang J, Ye J, Yuan C, Fu Q, Zhang F, Zhu X, Wang L, Gao P, Shu G, Jiang Q and Wang S: Exogenous $\mathrm{H}_{2} \mathrm{~S}$ exerts biphasic effects on porcine mammary epithelial cells proliferation through PI3K/Akt-mTOR signaling pathway. J Cell Physiol 233: 7071-7081, 2018.

14. Sciascia Q, Sales F, van der Linden D, Wards N, Oliver M, Blair H and McCoard S: Nutritional plane of twin-bearing ewes alters fetal mammary gland biochemical composition and mTOR/MAPK pathway signaling. J Anim Sci 93: 699-708, 2015.

15. Gao HN, Hu H, Zheng $\mathrm{N}$ and Wang JQ: Leucine and histidine independently regulate milk protein synthesis in bovine mammary epithelial cells via mTOR signaling pathway. J Zhejiang Univ Sci B 16: 560-572, 2015.

16. Li L, Liu L, Qu B,Li X, Gao X and Zhang M: Twinfilin 1 enhances milk bio-synthesis and proliferation of bovine mammary epithelial cells via the mTOR signaling pathway. Biochem Biophys Res Commun 492: 289-294 2017.

17. Lim S and Kaldis P: Cdks, cyclins and CKIs: Roles beyond cell cycle regulation. Development 140: 3079-3093, 2013. 
18. Park SY, Jeong MS, Han CW, Yu HS and Jang SB: Structural and functional insight into proliferating cell nuclear antigen. J Microbiol Biotechnol 26: 637-647, 2016.

19. Xiong Y, Hannon GJ, Zhang H, Casso D, Kobayashi R and Beach D: p21 is a universal inhibitor of cyclin kinases. Nature 366: 701-704, 1993.

20. Meng Y, Yuan C, Zhang J, Zhang F, Fu Q, Zhu X, Shu G, Wang L, Gao P, Xi Q, et al: Stearic acid suppresses mammary gland development by inhibiting PI3K/Akt signaling pathway through GPR120 in pubertal mice. Biochem Biophys Res Commun 491: 192-197, 2017.

21. Meng Y, Zhang J, Yuan C, Zhang F, Fu Q, Su H, Zhu X, Wang L, Gao P, Shu G, et al: Oleic acid stimulates HC11 mammary epithelial cells proliferation and mammary gland development in peripubertal mice through activation of CD36-Ca2 ${ }^{+}$and PI3K/Akt signaling pathway. Oncotarget 9: 12982-12994, 2018.

22. Zhang S, Bian H, Li X, Wu H, Bi Q, Yan Y and Wang Y: Hydrogen sulfide promotes cell proliferation of oral cancer through activation of the COX2/AKT/ERK1/2 axis. Oncol Rep 35: 2825-2832, 2016.

23. Liu D, Wang Z, Zhan J, Zhang Q, Wang J, Zhang Q, Xian X, Luan $\mathrm{Q}$ and Hao A: Hydrogen sulfide promotes proliferation and neuronal differentiation of neural stem cells and protects hypoxia-induced decrease in hippocampal neurogenesis. Pharmacol Biochem Behav 116: 55-63, 2014.

24. King AL, Polhemus DJ, Bhushan S, Otsuka H, Kondo K, Nicholson CK, Bradley JM, Islam KN, Calvert JW, Tao YX, et al Hydrogen sulfide cytoprotective signaling is endothelial nitric oxide synthase-nitric oxide dependent. Proc Natl Acad Sci USA 111: 3182-3187, 2014

25. Olas B: Hydrogen sulfide in signaling pathways. Clin Chim Acta 439: 212-218, 2015.

26. Dong XB, Yang CT, Zheng DD, Mo LQ, Wang XY, Lan AP, Hu F, Chen PX, Feng JQ, Zhang MF and Liao XX: Inhibition of ROS-activated ERK1/2 pathway contributes to the protection of $\mathrm{H} 2 \mathrm{~S}$ against chemical hypoxia-induced injury in $\mathrm{H} 9 \mathrm{c} 2$ cells. Mol Cell Biochem 362: 149-157, 2012.

27. Liu M, Li Y, Liang B, Li Z, Jiang Z, Chu C and Yang J: Hydrogen sulfide attenuates myocardial fibrosis in diabetic rats through the JAK/STAT signaling pathway. Int J Mol Med 41: 1867-1876, 2018.

28. Yang B, Bai Y, Yin C, Qian H, Xing G, Wang S, Li F, Bian J, Aschner M and Lu R: Activation of autophagic flux and the Nrf2/ARE signaling pathway by hydrogen sulfide protects against acrylonitrile-induced neurotoxicity in primary rat astrocytes. Arch Toxicol 92: 2093-2108, 2018.

29. Yang F, Zhang L, Gao Z, Sun X, Yu M, Dong S, Wu J, Zhao Y, $\mathrm{Xu}$ C, Zhang W and Lu F: Exogenous H2S protects against diabetic cardiomyopathy by activating autophagy via the AMPK/mTOR pathway. Cell Physiol Biochem 43: 1168-1187, 2017.

30. Liu M, Li Z, Liang B, Li L, Liu S, Tan W, Long J, Tang F, Chu C and Yang J: Hydrogen sulfide ameliorates rat myocardial fibrosis induced by thyroxine through PI3K/AKT signaling pathway. Endocr J 65: 769-781, 2018.

31. Gao P, Zhang AL and Zhong YY: Separation, culture and identification of sow ovarian granulose cells. Guangdong Agric Sci: 131-135, 2014 (In Chinese).

32. Ball SM: The development of the terminal end bud in the prepubertal-pubertal mouse mammary gland. Anat Rec 250: 459-464, 1998
33. Zhang M, Xu J, Wang T, Wan X, Zhang F, Wang L, Zhu X, Gao P, Shu G, Jiang Q and Wang S: The dipeptide pro-gly promotes IGF-1 expression and secretion in HepG2 and female mice via PepT1-JAK2/STAT5 pathway. Front Endocrinol (Lausanne) 9: 424, 2018.

34. Ye J, Ai W, Zhang F, Zhu X, Shu G, Wang L, Gao P, Xi Q, Zhang YL, Jiang Q and Wang S: Enhanced proliferation of porcine bone marrow mesenchymal stem cells induced by extracellular calcium is associated with the activation of the calcium-sensing receptor and ERK signaling pathway. Stem Cells Int 2016: 657-671, 2016.

35. Luo XY, Jiang XK, Li J, Bai Y, Li Z, Wei P, Sun S, Liang Y, Han S, Li X and Zhang BY: Insulin-like growth factor-1 attenuates oxidative stress-induced hepatocyte premature senescence in liver fibrogenesis via regulating nuclear p53-progerin interaction. Cell Death Dis 10: 451, 2019.

36. Roy JR, Chakraborty S and Chakraborty TR: Estrogen-like endocrine disrupting chemicals affecting puberty in humans-a review. Med Sci Monit 15: RA137-RA145, 2009

37. Hu X, Luan L, Guan W, Zhang S, Li B, Ji W and Fan H: Hydrogen sulfide attenuates isoflurane-induced neuroapoptosis and cognitive impairment in the developing rat brain. BMC Anesthesiol 17: 123, 2017.

38. Mani S, Cao W, Wu L and Wang R: Hydrogen sulfide and the liver. Nitric Oxide 41: 62-71, 2014

39. Guo Q, Feng X, Xue H, Teng X, Jin S, Duan X, Xiao L and Wu Y: Maternal renovascular hypertensive rats treatment with hydrogen sulfide increased the methylation of AT1b gene in offspring. Am J Hypertens 30: 1220-1227, 2017.

40. Pichette J, Fynn-Sackey N and Gagnon J: Hydrogen sulfide and sulfate prebiotic stimulates the secretion of GLP-1 and improves glycemia in male mice. Endocrinology 158: 3416-3425, 2017.

41. Askari H, Seifi B, Kadkhodaee M, Sanadgol N, Elshiekh M, Ranjbaran $M$ and Ahghari P: Protective effects of hydrogen sulfide on chronic kidney disease by reducing oxidative stress, inflammation and apoptosis. EXCLI J 17: 14-23, 2018.

42. Wang SC: PCNA: A silent housekeeper or a potential therapeutic target? Trends Pharmacol Sci 35: 178-186, 2014.

43. Zhou R, Chen H, Chen J, Chen X, Wen Y and Xu L: Extract from astragalus membranaceus inhibit breast cancer cells proliferation via PI3K/AKT/mTOR signaling pathway. BMC Complement Altern Med 18: 83, 2018.

44. Zhou H, Jiao G, Dong M, Chi H, Wang H, Wu W, Liu H, Ren S, Kong M, Li C, et al: Orthosilicic acid accelerates bone formation in human osteoblast-like cells through the PI3K-Akt-mTOR pathway. Biol Trace Elem Res 190: 327-335, 2019.

45. Yu JS and Cui W: Proliferation, survival and metabolism: The role of PI3K/AKT/mTOR signalling in pluripotency and cell fate determination. Development 143: 3050-3060, 2016.

46. Rosen JM: On hormone action in the mammary gland. Cold Spring Harb Perspect Biol 4: a013086, 2012.

47. Mallepell S, Krust A, Chambon P and Brisken C: Paracrine signaling through the epithelial estrogen receptor $\alpha$ is required for proliferation and morphogenesis in the mammary gland. Proc Natl Acad Sci USA 103: 2196-2201, 2006.

48. Zhou Y, Li S, Li J, Wang D and Li Q: Effect of microRNA-135a on cell proliferation, migration, invasion, apoptosis and tumor angiogenesis through the IGF-1/PI3K/Akt signaling pathway in non-small cell lung cancer. Cell Physiol Biochem 42: 1431-1446, 2017. 